future is bringing us-a united, harmonious body of trained men, whose endeavor is to carry forward the banner of science, not for personal advantage, but for the glory of the science to which we have dedicated our lives.

Charles E. Bessey

\section{RECENT EXPLORATIONS IN SIBERIA}

ACCORDING to recent information received from the American Consul at Vladivostok (transmitted to the Dept. of State, Sept. 10, 1912), and from other sources the following scientific exploration has been carried on during the current year in the Russian far east:

An important work was carried on in Siberia by the Russian Geological expeditions sent out to look for new gold deposits. The Russian Mining Department had expeditions in the Bargusin district on the Zeia River, in Minusinsk and in Kamchatka. The Russian Mineralogical Society was studying Lake Ingel in the Achinsk district. The Russian Geological Society has also begun an extensive study of the Kalbin Mountains in the Ust-Kamennogorsk district on the left bank of the river Irtish, where three independent parties are working at present. A Russian Gold Mining Company is studying the river Kolba, for which purpose three professors of the Tomsk University have been engaged. The Russian Geological Society has also sent out an expedition to study the country on the river Yenisei from Krasnoyarsk down to Dixon Island, situated in the Arctic Sea about two miles from the mouth of the Yenisei River. The purposes of this expedition are the study of the magnetism of the earth, and the definition of the astronomical coordinates for the northern sea route. An auxiliary motor schooner has been sent to the village Dudinskoe to serve as a temporary magnetic laboratory. The Yenisei River will also be studied from a botanical point of view, and the fish resources of the river are to be investigated.

The director of the Irkutsk Laboratory is making magnetic observations on the Lena River down to its ostuary, where the region of the maximum magnetic force is located. The Colonization Department is making studies of the flora and soil in the Semiretchie, Barabinskaia Steppes in Kainsk and Mariynsk districts and in Akmolinsk Province.
The Russian Society for the Study of Asia is investigating the unknown ruins on the right bank of the river Obi in the Barnaul district. Bones of animals and birds, stone and bone weapons and articles of bronze and copper have been found, as well as some fragments of pottery with ornaments belonging to an old civilization.

Dr. A. Hrdlička, of the United States National Museum, has been engaged in anthropological exploration along the upper Yenisei River, on the Selenga, and in northern Mongolia.

The Altai is attracting special interest and several well equipped expeditions are working there on various lines.

Siberia, and especially the Russian Far East, seem to attract a great deal of attention in Europe. The French Department of Education, the Geographical Society and the Musaum of Natural and Historical Knowledge have sent Daniel Busson with assistants to Siberia to prepare ethnographical, anthropological and natural history collections, as well as to take photographs and moving pictures. From Irkutsk they are to go to the Transbaikal, and from there to Yakutsk by the Lena River and from the river Kolima to Vladivostok. Much interest is manifested in scientific circles, as well as by students of economics, in regard to this almost unexplored and unexploited country which is so rich in opportunity for the seeker after truth.

Professor George Mixter, of Boston, has recently concluded a successful scientific expedition and hunting trip in the vicinity of Lake Baikal under the auspices of the Smithsonian Institution, Washington.

A Russian expedition has been sent out from St. Petersburg to examine the coasts of the Okhotsk Sea, the valley of the Anadir River close to Behring Straits, and the Gischiti and Aldon valleys. The chief of the expedition is Mr. P. I. Polevoi, a learned geologist and mining engineer, who is accompanied by topographers of the army.

It is further reported that the following expeditions have or will also visit Siberia:

1. An expedition to the Altai Mountains by Professor Lyman and Mr. Hollister for the purpose of making a collection of plants and animals for the United States National Museum and Harvard University.

2. Dr. Stanislav Hanzlik, professor of Prague University, to make a study of climatical and meteorological conditions of the Russian Far East. 
3. Sven Johan Ernandero, a Swedish explorer, to make a botanical study of western Siberia.

It should also be remarked that the matter of perfecting the northern route from Vladivostok to European ports via Behring Straits (so successfully navigated last year from Europe as far as the Yenisei River by the English navigator, Captain Webster, and from Vladivostok to Kolima River by a Russian vessel), and the charting of the new uncharted coast lines in many places on this route, is receiving attention from a special Russian expedition which sailed from Vladivostok at the opening of navigation this year. They will winter in the Arctic Sea and proceed next year on their voyage.

\section{A. HRDLIČKA}

\section{THE REORGANIZATION OF THE MEDICAL DEPARTMENT OF THE UNIVERSITY OF CALIFORNIA}

Ar a meeting of the regents of the University of California in December, 1911, the Committee on Medical Instruction recommended that the departments of the Medical School in Berkeley and San Francisco be brought together in San Francisco as soon as possible, that the clinical years be put upon an academic basis, and that a proper teaching hospital and proper laboratories be provided in order to promote the best interests of the university as a whole, and of the Medical School in particular. It was declared the desire of the board to establish a medical school of the highest standard.

At a meeting in April, 1912, upon the recommendation of the Medical Faculty, the following plan of reorganization was adopted. Clinical instruction in the medical school is to be carried on in three main departments. Gynecology and obstetrics: it was decided to put this department upon an academic basis at once and to allot full academic salaries for a professor and an assistant. (2) Medicine: this department to include pediatrics, neurology and dermatology. This department can not as yet be placed upon a full academic basis, but $\$ 2,300$ has been devoted to the payment of assistants for the current year. (3) Surgery: this department to include orthopedics, urology, ophthalmology, rhinology, otology and laryngology. As with medicine, there were not sufficient funds available this year to put the department upon a full academic basis, but $\$ 1,800$ was devoted toward paying three assistants.

In addition to the main departments, the work of the hospital pathologist was reorganized and an additional assistant professor of pathology was secured at a salary of $\$ 2,400$ a year. It was voted to grant $\$ 1,200$ for the work in radiography.

The budget voted to medicine 1912-13, for maintenance of the first two years, was:

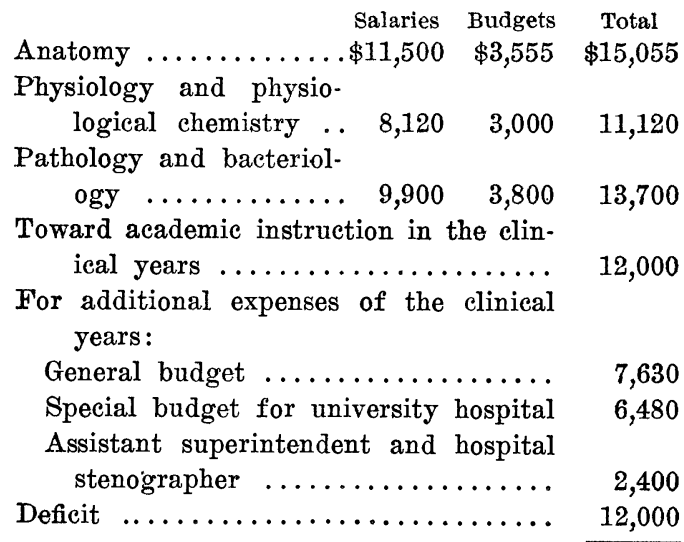

Total for medical instruction ...... $\overline{80,385}$

In accordance with the plans adopted by the regents, a movement is on foot to provide a new university hospital. The present plans aim at four units of forty to fifty beds each, to be devoted respectively to surgery, medicine, diseases of women and diseases of children. Money has already been given $(\$ 350,000)$ by private individuals to build and equip the departments of medicine and children's diseases. In order to carry on the work in the present buildings, the regents have granted $\$ 14,000$ for alterations in the hospital for accommodation of clinics, and $\$ 6,000$ for equipment of clinical and pathological laboratories. A children's ward has been added to the hospital.

\section{SCIENTIFIC NOTES AND NEWS}

THE following have been elected corresponding members of the Munich Academy of Sciences: Dr. Otto Struve, professor of astron- 